4. Павлюк, К.В. Формування доходів місцевих бюджетів. Фінанси України. 2006. № 4. С. $24-37$.

5. Хомов С.М. Громадський моніторинг як форма громадського контролю за діяльністю Державної фіскальної служби України. Часопис Академії адвокатури України. 2015. №4 (29). том 8. С. 138 - 143. URL : file:///C:/Users/User/AppData/Local/Temp/Chaau_2015_8_4_14.pdf

6. Ключка С. Громадський контроль як інструмент ефективного використання фінансових ресурсів місцевих бюджетів. Економіка: Наукові записки Інституту законодавства Верховної Ради Украӥни. 2016. № 3. URL: file:///C:/Documents\%20and\%20Settings/f1/\%D0\%A0\% D0\%B0\%D0\%B1\%D0\%BE\%D1\%87\%D0\%B8\%D0\%B9\%20\%D1\%81\%D $1 \% 82 \% \mathrm{D} 0 \% \mathrm{BE} \% \mathrm{D} 0 \% \mathrm{BB} / \% \mathrm{D} 0 \% 9 \mathrm{C} \% \mathrm{D} 0 \% 90 \% \mathrm{D} 0 \% 9 \mathrm{C} \% \mathrm{D} 0 \% 90 /$ Nzizvru_ $_{-}$ 2016_3_17.pdf.

DOI https://doi.org/10.30525/978-9934-26-147-3-10

\title{
СИСТЕМА РОЗВИТКУ ПРОФЕСІОНАЛІЗМУ ДЕРЖАВНОЇ СЛУЖБИ ФРАНЦУЗЬКОЇ РЕСПУБЛІКИ. ПЕРСПЕКТИВИ ВПРОВАДЖЕННЯ В УКРАЇНІ
}

\author{
Селіванов С. В. \\ кандидат наук з державного управління, \\ начальник Управління персоналу \\ Державної міграційної служби України \\ м. Київ, Украӥна
}

Об'єктивна необхідність вивчення європейського досвіду розвитку професіоналізму державної служби обумовлена тим, що європейська інтеграція залишається важливим стимулом для України в контексті реалізації реформ у системі державного управління, примноження та зміцнення кадрового потенціалу державної служби в умовах іiі модернізації.

На сьогодні більшість країн ЄС вже розпочали делегування, децентралізацію та індивідуалізацію функціональних обов'язків у сфері кадрової політики. При цьому Європейська модель компетентності державних службовців включає наступні складові [1, с. 52]: системне управління (бачення майбутнього, цільовому управлінні, роботі в команді та лідерстві); вирішення проблем (аналіз інформації, формування альтернатив, концептуальну гнучкість, прийняття рішень); оперативна ефективність (ініціативність, оперативний контроль, деле38 
гування повноважень, вміння зосередитися); трудові характеристики (ораторські здібності, навички до усних презентацій, впевненість в собі, вміння переконувати); особисті якості (енергійність, стресостійкість, мотивація, бажання розвиватись); управління з урахуванням середовища (усвідомлення зовнішнього середовища, розуміння політичних чинників, етика поведінки).

Цікавою складовою для України $\epsilon$ система розвитку професіоналізації державної служби у Франції, де саме професіоналізм визначений як один із пріоритетів організації державної служби. Такий підхід зорієнтований на забезпечення кар'єрної державної служби персоналом (система кар'єрного зросту), підготовленим до різноманітних аспектів державно-управлінської діяльності (від розробки до реалізації державної політики).

Стабільність кар'єри французького державного службовця грунтується, по-перше, на переміщеннях за вислугою років, а по-друге на гарантуванні державному службовцеві зайнятості протягом здійснення кар'єрного просування, адже, згідно з чинним законодавством, державний службовець не може бути звільнений з роботи до виходу на пенсію за віком (окрім випадків звільнення за власною ініціативою) i йому, за будь-яких реорганізацій, повинна бути надана можливість обіймати іншу посаду державного службовця [2].

Регулювання для початкового навчання державних службовців закріплюється, в основному, постановами та внутрішніми положеннями адміністративних шкіл, серед яких визначальне місце займають дві вищі школи, що підпорядковуються Прем'єр-Міністрові: 1) Національна школа адміністрації (Ecole Nationale d'administration (ENA) - здійснює підготовку чиновників для комплектування вищих кадрів адміністрації: членів Державної Ради, Рахункової палати, Фінансової інспекції (вищі органи управління), регіональних рахункових палат, адміністративних судів, Генеральної інспекції адміністрації, корпусів префектів, цивільних адміністраторів; 2) Паризький інститут політичних досліджень - незалежна від університетів державна установа наукового, культурного і професійного профілю.

Крім адміністративних шкіл у Франції (а їх - близько 50) також $\epsilon$ департаменти $з$ питань навчання всередині державних адміністрацій, які забезпечують підвищення кваліфікації. Приватний сектор також приймає активну участь у підготовці державних службовців, на підставі контрактів з адміністраціями.

Початком кар'єри державного службовця вважається підготовка до складання кваліфікаційного екзамену для вступу на державну службу, подальше навчання у вищезгаданих школах або в одному із п’яти 
регіональних інститутів державного управління. Студенти, які успішно склали вступні іспити, приймаються у школу в якості державних службовців та протягом навчання отримують зарплати. Термін початкового навчання залежить від школи. Наприклад, термін навчання становить 24 місяця в ENA, 1 рік - в регіональних інститутах адміністрації (IRA) [3, с. 8].

Метою навчання $\epsilon$ не лише отримання знань, але i набуття необхідних навичок. Тому освіта у школах поділяється на стажування та навчання. У ENA стажування займає особливе місце: близько 2/3 навчання у школі припадає на стажування. Для всіх студентів, французів чи іноземців, передбачається, що протягом стажування вони будуть відповідальними за виконання певної роботи, а не просто спостерігатимуть за виконанням роботи іншими. Студенти вважаються державними працівниками, що мають обов'язки та зобов'язання, визначені цим статусом. Вони відповідальні за певні завдання та дуже різноманітні місії і повинні швидко завоювати довіру особи, що відповідальна за їх стажування [3, с. 7-8].

При цьому Ю.В. Яшина зауважує, що у Франції існують різні форми навчання: курси підвищення кваліфікації; навчання, пов'язане 3 просуванням працівників державного апарату по службі (підготовка до професійних конкурсів чи конкурсів, які організуються для тих, хто проходить службу на певній посаді, з метою підвищити чин чи перейти до іншого корпусу); удосконалення професійної підготовки, коли працівник для самостійних занять чи наукових розробок, що є суспільно корисними, тимчасово відраховується зі служби до резерву чи отримує відпустку для підвищення кваліфікації [4].

У свою чергу М. Міненко серед основних форм підвищення кваліфікації виокремлює ще й відпустки для підготовки (максимальна тривалість відпустки - три роки, але вона може бути розділена й надається тільки для проходження підготовки за згодою держави за умови, що агент відпрацює щонайменше три роки в адміністрації. Службовець, який скористався такою відпусткою, зобов'язується залишитися на державній службі на період утричі більший від того, за який він отримував попередні виплати) [5].

Зауважимо, що у Франції державні службовці не витрачають своїх коштів на підвищення кваліфікації. Згідно інформації, яку наводить Р. Піганьоль, для державної цивільної служби витрати на навчання становлять $6,6 \%$ від загального фонду заробітної плати $(3,3 \%$ для початкового навчання і 3,3\% для підвищення кваліфікації), у т. ч. винагороди державних службовців у процесі навчання. Ці затрати $\epsilon$ вимірювальними: 6,8 млн. навчальних днів на рік, 61\% персоналу 
проходять навчання принаймні один раз на рік, державні службовці $є$ більш підготовленим персоналом, ніж працівники, що зайняті у бізнесcфepi [3].

Отже, до позитивних сторін французької системи, спрямованої на розвиток професіоналізму державних службовців, слід віднести: високоякісний менеджмент людських ресурсів та відповідність навчальних програм існуючим потребам у навчанні; висока елітарність державної служби, яка за конкурсної системи відбору підтримується завдяки “освітній монополії” декількох навчальних закладів на підготовку держслужбовців; кадрова стабільність державного апарату та престижність державної служби в суспільстві; дієва методологія оцінки якості навчальних курсів і відстежування подальшого професійного розвитку колишніх студентів адміністративних шкіл; наявні гарантії повільного, але вільного кар'єрного просування; розвинена система гарантій правової та соціальної захищеності службовця; та ін. Серед головних недоліків привертає увагу пріоритетність стажу роботи над діловими якостями та професіоналізмом, а також низький рівень мобільності.

\section{Література:}

1. Малиновський В. Державне управління : навч. посібник / В. Малиновський - Луцьк : Вежа, 2000. - С. 54-55.

2. Selivanov S. Personal potential of public service as innovative object of scientific research in Ukraine / Obushna N., Selivanov S. // East European Scientific Journal: №1 (29), 2018 part 1, Printed in the "Jerozolimskie 85/21, 02-001 Warsaw, Poland", 2018. - C. 48-53.

3. Mcquail, D., Windahl, S. Communication models : for the study of mass communications. 2nd ed. London: Longman, 1993. viii, -229 p.

4. Learning and Developmental Opportunities // Public Service Division/ Singapore Government. - Режим доступу: http://www.psd.gov.sg/ content/psd /en/care\% ersinpsd/whypsd/learning_and_developmental_op\% portunities. html

5. Linda M. Kutilek, Gail J. Gunderson, Nikki L. Conclin (2002). A Systems Approach : Maximizing Individual Career Potential and organizational Success. Journal of Extension, 40, № 2. - Retrieved from: http://www.joe.org/joe/2002april/al.php 